\title{
LIBERAL DEMOCRACY: ABSOLUTIST EU RULE OF LAW CONDITIONALITY OR PLURALISTIC BARGAINING CHIP?
}

\author{
Anja Matwijkiw* \& Bronik Matwijkiw ${ }^{* *}$
}

\author{
"Indiana University Northwest (USA) \\ (amatwijk@iu.edu) \\ ${ }^{* *}$ Southeast Missouri State University (USA) \\ (bmatwijkiw@semo.edu)
}

\begin{abstract}
EU membership accentuates values. The current emphasis is a case of EU idealism, of stricter conditionality in response to political ideology and governance. Democracy is tantamount to liberal democracy, but at the same time pluralism is an integral part of the conditionality. This raises the question about the countryspecific maneuvering scope or - if EU candidate countries and Member States (are seen to) deviate from a non-negotiable ideal-inappropriate manipulation. While the authors do not address absolutism per se, they proceed on the premise that the "European perspective" disallows any value dilution, thereby maximizing the conflict and identity crisis which Poland and Hungary have caused and which have overshadowed accession talks for candidate countries. One intention is to contextualize the debate and dispute about values by incorporating interdisciplinary insights. Another is to challenge the (European perspective on the) rule of law cluster, inter alia, with the illiberal measures that Denmark has adopted.
\end{abstract}

Keywords: Conditionality, EU Membership, European Perspective. 


\title{
DEMOKRACIA LIBERALE: KUSHTËZIM ABSOLUTIST I SHTETIT TË SË DREJTËS APO PAZAR PLURALIST I BE-SË
}

\author{
Anja Matwijkiw" \& Bronik Matwijkiw ${ }^{* *}$ \\ *Indiana University Northwest (SHBA) \\ (amatwijk@iu.edu) \\ *** Southeast Missouri State University (SHBA) \\ (bmatwijkiw@semo.edu)
}

\begin{abstract}
Abstrakt
Anëtarësimi në BE thekson vlerat. Theksi aktual është një rast i idealizmit të BE-së, i kushtëzimit më të rreptë kundrejt ideologjisë politike dhe qeverisjes. Demokracia është e barazvlershme me demokracinë liberale, por në të njëjtën kohë pluralizmi është pjesë përbërëse e kushtëzimit. Kjo ngre pyetjen në lidhje me qëllimin e manovrimit specifik për një vend ose - nëse vendet kandidate në BE dhe shtetet anëtare (shihen se) devijojnë nga një ideal i panegociueshëm - manipulim të papërshtatshëm. Ndërsa autorët nuk trajtojnë absolutizmin në vetvete, ata vazhdojnë me premisën se "perspektiva evropiane" nuk lejon çdo zbehje të vlerës, duke maksimizuar kështu konfliktin dhe krizën e identitetit që Polonia dhe Hungaria kanë shkaktuar dhe që kanë lënë në hije bisedimet $e$ anëtarësimit për vendet kandidate. Një synim është që të kontekstualizohet debati dhe mosmarrëveshja rreth vlerave duke përfshirë njohuri ndërdisiplinore. Një tjetër është të sfidohet rrjedha (perspektiva evropiane) mbi sundimin e ligjit, ndër të tjera, me masat joliberale që Danimarka ka miratuar.
\end{abstract}

Fjalë kyçe: kushtëzimi, anëtarësimi në BE, perspektiva europiane.

\section{The EU Course: Values, Values, and Values}

It is no exaggeration to claim that EU accession and integration is a value project, in effect, an identity politics test. On a superficial level, this consists in confirming the "European perspective" which is anchored in core European values (1). On a philosophical level, however, the controversy that has resulted from several decades of identity politics discourse may raise its complex head - with difficult questions about the appropriate response to, according to Francis Fukuyama's analysis, recognition and redistribution (2). These categories capture the contest between politics and economics, more precisely, between identity and class (inequality). By analogy to M. Cherif Bassiouni's discovery of the manner in which realpolitik may co-opt organizations that promote peace and justice (3), Fukujama points to the way that the left versus right divide has created an ironic advantage for the right, which is recycling the victimization cum marginalization rationale with the use of a cultural issues narrative and sanctioned by neonationalism and neoconservatism. The game premises have been reset. The left's vulnerable stakeholder constituency, minorities, immigrants and refugees, women and LGBT people, has had their materially and historically grounded identity replaced with a 
self-fashioned essence. In turn, this development has muted the thesis of redistribution in favor of capitalism, meaning that a traditional national identity is pushed as a patriotic and neoliberal agenda that can easily co-opt recognition (4).

Obviously, promoting the interests of a narrow concentric-circle membership of our kind of people is not the official EU goal behind the European perspective, and yet the clash between the two competing forms of identity politics cannot be ignored. At the same time, the synthesis of recognition and redistribution arguably constitutes a component of the principle of solidarity, which is increasingly called together with respect for the rule of law (5). If the distinction between "petty" and "grand" corruption is observed, the serious and systematic violations that result from the latter are consistent with the notion of economic violence as a conflict-causality and, ipso facto, anti-corruption efforts must be subsumed under the protection of fundamental human rights (6). This is a key area of attention concerning the Western Balkans' accession to the European Union (EU) irrespective of whether a particular country is in the process of commencing integration talks (potential candidate country) or it is in the final stages of taking steps towards full membership (official candidate country).

At the philosophical level, the implications of an application of the kind of Hegelian dialectics that Fukuyama's analysis is predicated on would entail a redefinition of the European perspective provided the politics/economics constellation is defined along the lines of the capitalism versus socialism divide that traditionally has informed the right and the left (7). As a minimum, the implications would problematize the liberal democracy premise that is, in fact, one of the Copenhagen criteria (8). Economically, this is coupled with a marketplace that also relies on market freedoms (9). The last criterion of the triple clause for a negative test as a European fragile state concerns the "grand strategy", namely the acquis (10). In the case of the Western Balkans, the emphasis has been placed on the protection of fundamental human rights because of the region's "worrying democratic setback", the threat of "illiberal democracy regimes" (11). In soft power terms, this threat is not just about polarization; it is also about superpower politics for China and Russia share the EU's geopolitical stake in the Western Balkans. In an attempt to maintain its influence, the EU began to rebalance pragmatism and idealism, i.e., respect cum recognition of European values in the form of the 2020 revised methodology for enlargement (12). The transition from the classical model to the new counterpart is tailored to the task of replacing so-called box ticking with a full commitment, with best practices constancy. The bar was raised and, at the same time, reciprocity and interdependency were accentuated with the four principles of "credibility", "predictability", "dynamism" and "political steer" and six thematic "policy clusters", as well as bilateral conditions ("regional cooperation" and "good neighborly relations") (13). In the case of the fourth principle, the EU is aiming for "stronger political steer(ing)" and "stronger monitoring" (14). Although diplomatically worded, the argument is conscious of the collective security risk and the superpower competition: "Given what is at stake, it is time to put the political nature of the process front and centre" (15). It is hardly surprising that ethical values like trust are added (16). EU integration may or may not be a sincere "top priority" (17). Then again, EU leaders have to deliver too; and "opening more chapters in one go" (cf. 2020 revised methodology), thereby also allowing an accelerated accession, is seen as a good faith strategy of counteracting any waiting-game frustration which subtracts from their trust in us and our credibility (18). Apart from "cross-fertilisation of efforts beyond individual chapters" pursued in thematic 
policy clusters and with a view to "structural weaknesses (...) in particular in the area of the "fundamentals"" that encompasses fundamental rights (19), there has to be increased responsiveness from the EU to secure a win-win outcome. Responsiveness covers the extremes of the spectrum: more involvement and reversibility. Once again, however, the goal is to secure balance. EU flexibility should not compromise EU values. The detection of structural weaknesses is a system failure indicator that suggests that the particular candidate country depends on $u s$ (cf. stronger steering and monitoring) during the process - the rate of which is otherwise a question of the country's own merits and specific situation as accounted for in annual reports. The realization is that the expected transformation through reform/s is a case of mixing objectivity and clarity (as regards conditionality) with contribution, collaboration, control, correction and even censure (cf. the option of withdrawing concessions) - with positive and negative consequences respectively. The enhanced predictability is the EU's tool to steer the candidate countries toward membership. Success is not guaranteed, but the thematic clusters aim at more dynamism (20). Together with the idea of shared responsibility, superior accountability is highlighted (21). If the political will of leaders to implement the benchmarks against which a country's performance is measured is purely nominal (cf. box ticking) as opposed to evidence-based, incentivised and rewarded progress-should be replaced by decisive measures proportionally sanctioning any prolonged stagnation or backsliding (22).

While dynamism provides an opportunity for acceleration, there is also room for tough learning lessons. If the EU is not proactive, experience shows it may be too late to make a real difference as regards performance, as illustrated by the challenges posed by Poland and Hungary.

"Observers and commentators talk about a post-Cold War democracy crisis, about no oversight and no 'brakes' for Member States, including countries that practice autocratic legalism, that is, populism. If a common foreign policy is an illusion, the EU cannot be seen as a geopolitical superpower (...). The R2P principle has been forgotten for the same reason. Other experts may point to the excessive 'moral internationalism' involved in what is the key to genuine solidarity" (23).

Arguably, article 7 proceedings against Poland and Hungary have only "limited effects" (24). Infringement procedures against the two countries were initiated by the Commission and the European Parliament for "clear risk of a serious breach by a Member State of the values referred to in article 2" (article 7 of the TEU), which are "values of respect for human dignity, freedom, democracy, equality, the rule of law and respect for human rights, including the rights of persons belonging to minorities" (article 2 of the TEU) (25). Limited effects point, of course, to deep-rooted issues. Irrespective of the exact diagnosis, Poland and Hungary are bound to set examples for candidate countries qua their status as Member States. As it happens, other examples exist which seem to put countries on the wrong path. Prior to taking a closer look at these, the remaining premises for assessment should be inserted

\section{Solidarity, Redistribution... or No Social and Economic Human "Rights"}

Apart from a joint effort to tackle the coronavirus, the main outcome of the EU Zagreb Summit of 6 May 2020 was the Zagreb Declaration that reconfirmed the European perspective "albeit without mentioning enlargement" (26). The emerging trend of calling 
solidarity and anti-corruption as integral aspects of the rule of law was also reconfirmed in the process of signaling constancy as regards the stricter conditionality that the European Commission has advocated since 2006 (27). The EU Council decision that had been expected before the Zagreb Summit - whether to open accession negotiations with Albania and North Macedonia - had come in on 25 March. It was a "green light" subject to final endorsement by the European Council Members (28). This was secured too; and on 19 June 2020, President Ursula von der Leyen stated: "Today marks the start of the journey to a bigger and stronger European Union. And this decision is in the European Union's geostrategic interest" (29). On 1 July 2020, it was announced that the frameworks "integrate the revised enlargement methodology" and, furthermore, that "the objective of the negotiations is that Albania and North Macedonia adopt the EU acquis in its entirety and ensure its full implementation and enforcement upon accession" (30).

It is noteworthy that "[c]redibility is reinforced through an even stronger focus on fundamental reforms, starting with the rule of law, the functioning of democratic institutions and public administration as well as the economy of the two countries" (31). Liberal policies must be comprehensive, thereby precluding a domestic state of affairs that resembles U.S. President Biden's description of "authoritarian capitalism" (32). Since it appears that EU values, i.e., the European perspective of democracy, rule of law and fundamental human rights are the "engines of economic integration" (33), certain ideological buttons are activated. The cause-and-effect model is not value-neutral. Instead, it reverses the classical free market thinking whereby the economic system paves the path for the political order. E.g., Milton Friedman makes it hold that capitalism may lead to a liberal democracy but that this does not happen with necessity (meaning authoritarian capitalism may be the outcome). A transition from market freedoms and forces to fundamental civil and political rights is desirable in his opinion, but Friedman insists on the separation of business and government and, with this, the political pressure is off. In the case of the EU, however, the political order and the economic system are linked, just as Fukuyama's recognition category is the driver of economic integration, of success when it comes to the "magnet", that the EU can "help countries recover, grow and prosper" (34).

The deal is the wealth of a nation (cf. redistribution) in return for fidelity to liberal democracy. The rule of law cluster and the Copenhagen criteria require, expressis verbis, "respect for and protection of minorities" as well as individual rights. Another implication of signing off on this type of order consists in the fact that talk about "structural weaknesses" comes without any revolutionary potential. The government is the primary guarantor of fundamental rights.

This is probably why EU experts like Andrea Sangiovanni distinguishes between national solidarity and member state solidarity (35). He does more than this, though. The liberal Principle of Freedom under Responsibility is applied to financial self-sufficiency requirements (36). The rationale behind these, as found in Directive 2004/38/EC of 24 April 2004, is to prevent phenomena like "benefit tourism" so that Member States can limit the fiscal burden of inactive migrants and, more generally, the welfare magnet (37). Apparently, that is how it should be. Sangiovanni uses his own account as a launching pad for the statement that "it would be inappropriate to (...) apply the same principles of social solidarity to the EU level as (...) the state level" (38). A balance between market access and solidarity principles can be reached on the basis of evolving EU legislation and case law (39). Notwithstanding, Sangiovanni draws the line in the sand by arguing 
against all internationalist versions of coercion-based (re)distributive justice - while conceding that a model of European solidarity (cf. member state solidarity) is a plausibility (40). Since there can be no "true social contract" for the European polity without prior reflection on solidarity and the criteria of (re)distributive justice, Sangiovanni recommends political and ethical philosophy, thereby also conceding that interdisciplinary insights may ward off a crisis of legitimacy (41). Sangiovanni's choice of philosophers include Robert Nozick, John Rawls, and Ronald Dworkin. EU policymakers' reading list does not transcend the liberal and capitalist framework. Furthermore, the outlooks leave their clear footprints in the conceptualization of rights. Critical discourse must include credentials-checking to avoid taking too much for granted about ideological versus logical aspects of interpretation.

A link between voluntarism and international redistribution (cf. member state solidarity) is in conformity with the market idea of free exchanges between rational and informed agents. All narrow and broad versions of stakeholder theory that flow from corporate social responsibility doctrine confirm this (42). The difference between theorists like Friedman and Freeman lies in the radical tenets of Friedman's premises, especially his distinction between capitalism and socialism in terms of totalitarianism (43). Rights are not to be conflated with the state of affairs in a socialist society, which "cannot also be democratic" (44). The distinction between liberal democracy and economic "democracy" is a dichotomy. The assumption of incompatibility entails that values like freedom and the welfare state are mutually exclusive, for the loss of civil liberty is the price for social and economic "rights". The incompatibility thesis works together with the Ought Implies Can Principle construed as a meta-norm that makes it impossible to derive real rights cum claim-rights from positive duties (45). The narrow stakeholder concept of rights stricto sensu adopts the logical correlativity thesis, but it also relies on the extra-correlativity idea that rights-recognition is mediated by rights-protection. This is the point at which the narrow approach excludes social and economic claims as rights. The broad counterpart, on the other hand, establishes rights through the basicness of interests, whereas the otherregarding duties together with the controlling choices and powers relating to these (which the narrow models present as rights-credentials) are viewed as consequential measures of the conferment of rights. Unlike the narrow approach, the broad confirms values across the right-left spectrum, both autonomy, survival, physical and psychological integrity (civil/political rights) and subsistence and health (economic/social rights). Broadly, humanity-centricity delineates basic stakes that are elevated to rights to secure respect for the intended beneficiary.

"As demonstrated by advocates of [broad] Stakeholder Jurisprudence, the existence of international economic/social human rights norms is not contingent on the availability of resources or, for that matter, on controlling choices of duties (cf. discretionary powers). Conventional treaty law at the global level confirms this with a notion of programmatic duties, whereas instruments like the EU Social Charter takes the additional and progressive step of connecting social/economic rights and vulnerability, thereby using the implied insecurity as an argument for duty-reassignment from Self(-reliance) to public assistance" (46).

In principle, fundamental rights are claimable in all circumstances since they are the right reason to make things possible for protection. Friedman bans paternalism, but the counterproductive effect of disallowing restrictions for self-regarding action consists in the loss of freedom. A cancellation of the power to choose to waive those immunities that 
protects the individual's status as a rightholder in the first instance is necessary. Furthermore, the fallacies that guide the narrow exclusion of economic/social rights and give rise to "because positive rights are linked with positive duties, these cannot count as claim-rights" and "because there cannot be scarcity of non-interference, only negative duties give rise to real rights" inferences show that the narrow cum neoliberal position aims to discredit broad responsiveness to basic human needs, inter alia, by i) depicting "dignity" as the avoidance of freedom-deprivation; ii) "distributive justice" and "redistribution" as instances of "democratic" socialism; and iii) needs as paternalist subcategories that conceal "wants", the rank-ordering of which generate the preferences that set the market in motion (47). By associating needs with Karl Marx's philosophy, the contest between liberal democracy and illiberal redistribution becomes a question of ethics too, for the utilitarian strategy of benefiting most people through the promotion of welfare points to positive provisions that reduce free agents to means for an allegedly good agenda. The majority rule that is a component of liberal democracy should be separated from the relevant kind of majority tyranny, so the neoliberal implication is. However, while the broad alternative can accommodate utilitarianism, it is not automatically wedded to this (48). The position called Stakeholder Jurisprudence recalibrates stakes in justice that threaten to negate protections of minorities and individual rights. To minimize such threats, the Ethics Pillar is advanced in the form of co-constitutive rights-principles, and methodologically tailored to clarifying basic human needs as global imperatives (49).

\section{Member States and the Slippery Slope}

It is thought-provoking to consider EU's article 7 proceedings against Poland and Hungary in the light of market philosophies that developed into approaches that make talk about "stakeholders" a placeholder for anybody who affects or is affected by polices. Rights help to illustrate the narrow/broad directions. That granted, the majority tyranny criticism may suggest that minority stakeholders are made to matter less in terms of rights. If illiberalism is upheld by the people's surrender of sovereignty as vested in the Parliament (cf. majority rule), narrow stakeholder outlooks do not declare a rule of law failure. The step of ratifying or acceding to international treaty law is crucial to the extent that the state incurs legally binding duties under conventional law, which qualifies as real law in comparison to international customary law. This is relegated to the realm of morality due to the lack of enforcement measures. However, if voluntarism is transferred to international law and international relations, a state-centric concept that stresses selfdetermination may result in right-wing nationalism, without translating realpolitik expediency tools used to reject multiculturalism into illegitimacy. By analogy to the way that the political right reconstructs the foundation for identity politics (cf. self-fashioned essence) in connection with victimization cum marginalization, the defense of cultural and nationalistic rights for $u s$ and our kind conveniently eschews socioeconomic criticisms. E.g., the current Polish regime has non-narrowly increased the government's support of the elderly, families, and the unemployed, just as it has non-narrowly introduced more plan economy measures (nationalization and centralization). To a large extent, the programs have been sponsored by the EU. Meanwhile, anti-EU rhetoric is set in the context of "fighting western decadence". According to Deputy Prime Minister Jarosław Kaczyński, the church is the "repository of the only moral system commonly 
known in Poland" and "rejection of it is nihilism" (50). Amidst embarrassing questions from philosophers like Jan-Werner Muller, "Could EU accommodate a dictatorship?", Poland's ruling Law and Justice party (PiS) responds against anti-Polish values and stakeholder constituencies, including LGTBQ groups, critical journalists and newspaper editors, independent media, and judges whose pro-government attitude is in doubt. The restrictions of women's reproductive rights (cf. ban on abortion that includes cases of "severe and irreversible fetal defect or incurable illness that threatens the fetus' life") exemplify the religious cum Catholic and conservative values that belong under the "God, Honor, and Fatherland" motto. As for judicial independence, Poland has adopted a series of controversial reforms, including penal measures, which erode the separation of powers. What is more, the EU is faced with a credibility challenge.

To suspend rights, the requirement is a unanimous decision in the EU Council (51). However, the COVID-19 pandemic caused a delay in that EU officials contended "EU ministers could not meet in person during this period" (52). In practice, this means that article 7 - invoked by the European Commission in 2017 - so far has not produced results. The same is true of the soft conflict-resolution measures the EU tried, e.g. dialogue and political distancing (53). Meanwhile, the tentative victory is bittersweet for Poland. In 2021, the government challenged the legality of a new plan to realign democratic backsliders with the European perspective, namely to link disbursement of funds from the EU budget with rule of law conditionality. Together with Hungary, Poland filed a complaint to the European Court at Justice (ECJ) (54).

Concerning Hungary's EU standing, the article 7(1) TEU procedure was also initiated in 2018 by the European Parliament as a consequence of similar concerns at the domestic level: judicial independence, freedom of expression, corruption, rights of minorities (including 2021 anti-LGBTIQ legislation cloaked as a pedophilia measure), and the situation of migrants and refugees. In the case of judicial independence, the national conservative Hungarian government passed the Enabling Act in 2020, which gives Prime Minister Viktor Orbán of the ruling right-wing Fidesz party the right to pass special executive decrees in response to the coronavirus outbreak. The necessity and proportionality of the state of emergency measures are being questioned by the EU. On 22 June 2021, the media reported that "Poland and Hungary sanctions procedure [are] back after [the] pandemic" and, therefore, it is too early to predict if Hungary and its counterpart will be faced with negative consequences that can make up for the nonexisting right to expel Member States (55). Commentators state that the way forward is through "the combination of actions before the Court of Justice of the European Union (CJEU) and the infringement proceedings" (56).

Value incompatibility in the context of a national conservative ideology need not be coupled with an appeal to our Christian traditions. Nevertheless, it is noteworthy that the 2007 Treaty of Lisbon replaced the proposed EU Constitution because the debate and the dispute about the latter escalated into a religious value fight about whether the Preamble should read something to the effect of "We are Christian" (57). Europe is polarized. Europe has an identity crisis. Poland and Hungary represent a minority at this point in time... but the future may hold surprises. Furthermore, the European perspective could arguably have been a target in the case of those countries that adopted the so-called burqa ban. Certainly, the copycat strategy that Denmark used to implement its criminalization of full-face coverings (cf. law L 219) is a case of legal boldness. Denmark copied France and Belgium after the European Court of Human Rights (ECtHR) upheld their bans but 
also at a point in time where Denmark could have accommodated the United Nations Human Rights Committee's (UNHRC) 2018 criticism. The judgment of the UNHRC, that the restriction of religious pluralism constitutes a violation of fundamental human rights, is not binding; but it does not follow from this that legitimacy is not adversely affected. The Jacques Delois Institute may be correct that the Scandinavian countries have "a strong approach" to the rule of law during elections, but what is Albania and other candidate countries to think about the fact that Denmark has followed a hard-liner illiberal rebranding course since 2001 to strengthen Danish values? Politically, the right and the left collaborated, and the many measures to limit the number and cost of asylum-seekers and refugees led to a serious deterioration of the humanitarian protection conditions before the tentative culmination of anti-immigration responses in the 2019 "paradigmshift" (cf. law L 140) where repatriation replaced integration (58). As for the ethnic and religious minority of Muslims of non-western origin who were trying to make the transition to Danish citizenship, a non-negotiable assimilation measure called the Constitutional Ceremony (cf. law L 80) tested the female applicant's respect for Danish values like transparency, openness and tolerance by forcing her to shake hands with male public officials to complete the naturalization process. The Danish government's goal to reduce the number and cost of them and their kind was partly premised on the Danish Social Democratic Party's belief that there is a "fundamental contradiction between a very liberal immigration policy and the survival of the welfare state" (59). This suggests, of course, that Friedman is correct about the contrast between freedom and (illiberal or totalitarian) welfare. He argues that vulnerable stakeholders are better off in laissez-faire capitalism. A self-regulating marketplace is a protective measure when it comes to nondiscrimination as a value because the market makes no judgment except in matters that pertain to economic activity and productivity (60). If the borders were open, the marginalized would avoid countries like Denmark that are persuaded by the reasonableness of establishing (cultural and nationalistic) rights of the Danes qua the majority, as reflected in the burqa ban rationale that also relies on secularism as an implicit premise (61). What matters is that newcomers are met with fairness in relation to economic opportunities (for financial self-sufficiency). Interestingly enough, Denmark is not a popular final destination country, nor is diversity a value that is embraced in the job market where the denial of systematic racism poses challenges (62).

The ECtHR's prioritization of the margin of appreciation in the case of S.A.S. v. France cannot but put a dent in the European perspective that is grounded in common values, whereas the margin is applicable "in matters of general policy, on which opinions within a democratic society may reasonably differ widely", meaning that domestic policymakers should be ascribed special weight to allow a "choice of society" (63). Apparently, Danish illiberal measures do not give rise to sufficient discrepancy to cause an implosion. However, if the situation in Poland and Hungary continues, this may be the clash and contradiction that will compel the other European Member States to insist on accountability, on conformity amidst internal disunity.

\section{The Devil's Advocate: Any Absolutes on "How To"?}

The doctrine of the margin of appreciation gives states latitude in balancing individual rights against (national(istic)) state interests, in the cases at hand, with the prioritization of our in-group form of coexistence at their expense. Liberal democracy's rule of law 
mixes respect and protection of minorities with individual rights and majority rule which opens the door to majority tyranny in the form of measures like the Danish burqa ban and handshake provision, as well as the tension between welfare state redistribution and humanitarian protections as opposed to examples of (Sangiovanni's) benefit tourism. The Danish reaction was facilitated by legal opt outs in the area of justice and home affairs, thereby raising doubts about the country's solidarity with EU policy (64). Both at home and abroad, Denmark has resorted to indirect deterrence as a strategy in the case of people it has a "desire to avoid" (65). Concerning the fundamental rights that Denmark restricts, these cut across the narrow/broad divide by virtue of affecting both basic civil/political rights and economic/social rights. While narrow versions of stakeholder theory maintain that the welfare state is (value-)incompatible with freedom, it is equally correct that some civil/political rights are politicized. E.g., narrowly freedom of association cannot remain a right if stakeholders are forced to accept unions and collective bargaining. The more socialized the market is, the more it becomes a match with redistribution. The vision of Europe's "social market economy" that is advanced in the 2021 European Pillar of Social Rights Action Plan is an example of left-wing "activists" who undermine the fabric of a free society, according to Friedman (66).

Setting aside the debate and dispute about the basis and the superstructure - and how one determines the other, commentators may ask about the appropriate response to internal EU disagreements. One question is about the subtle sub-distinctions for pluralism. If Denmark and other countries can restrict religious pluralism, then why shouldn't Poland and Hungary be permitted to use a religious rationale to limit, inter alia, access to abortion? The EU policy stance on the topic is that measures that roll back reproductive rights violate the principle of non-retrogression under international human rights law. In June of 2021, the European Parliament passed a resolution "that proclaimed the safe access to abortion is a human right" (67). The resolution was intended for countries like Poland, but objections were made:

"Abortion is not a human right", Rosa Estaràs Ferragut, a Spanish MEP from the EPP said during the plenary debate prior to the vote. "It could be a legal right, that's accepted in some member states, but it's not a human right".

She added: "You can't ideologize a human right, this is not democracy and this is not what I want to see in Europe" (68).

In July of 2021, a condemnatory response was delivered to Hungary's anti-LGBTQ+ legislation. A majority of 459 MEP voted in favor, whereas 147 opposed the interpretation of Hungary's ban of the promotion of homosexuality, gender reassignment, and the concept of sexuality deviating from the one assigned to a person at birth in educational materials as a "clear breach" of EU law (69). Hungary announced its refusal to repeal the law. Is the alleged discrimination disrespectful of EU values of tolerance; or are EU values of tolerance a zero-sum game - by analogy to Denmark's laws at the national level? After all,

"French President Emmanuel Macron has called the split over values between the liberal West and more conservative eastern countries such as Hungary and Poland a 'cultural battle' that damages EU unity" (70). 
The majority has the power to foundationally steer the EU away from pluralism, meaning that Poland and Hungary stand to lose their voting rights in the EU Council (outcome of article 7 proceedings), or their funds, or their credibility and the trust of the EU - or all of these - unless their illiberalism is transformed into our form of liberal democracy which can accommodate some deviations but not national conservative eastern outlooks. Currently, the EU considers the situation with a view to identifying the counter-measures that can put the outsiders straight or, alternatively, "leave the block" despite Hungary's claim that no discrimination of sexual minorities is occurring, that their rights are not at stake (71).

Is this a matter of perspective? Or, is the European perspective one that precludes the eastern outlooks because these are perceived as backwards? If so, would it be better to avoid the "stick" method and a too predictable value stalemate. Provided policymakers are open-minded, solutions may come from interdisciplinary insights. E.g., philosophical lessons from Ludwig Feuerbach may be incorporated, especially his work on religion and (value) projection. If the EU allowed some time... for the Christian and national conservative ideas to burn out, countries like Poland and Hungary would be able to celebrate the European perspective. Admittedly, epistemological (self-)emancipation competes with the type of materialism that argues that Feuerbach's concept of man as species is isolated from the historical process (72). With the mode of production as the primary category, historical materialism and the dialectical method that Marx and Engels pioneered depict religion as a feature of the bourgeois cum capitalist and liberal class society. In Marxist terms, the law is a reflection of the interests of the ruling class. It is a tool to maintain the status quo. Therefore, the burqa ban and the handshake provision are reactionary measures. As "the opium of the people", religious values can only be effectively eliminated by addressing the root causes: the oppression cum socioeconomic inequality. If the EU proceeded on the basis of moral internationalism, member state solidarity (cf. assistance) could lessen EU conflict. Instead, the recent "Polish Deal" that is tailored to the neediest appears to have strengthened populism. The EU may have lost its opportunity to use values (cf. recognition) as the gateway to the welfare magnet (cf. redistribution) despite the association of corruption and "economic nationalism" (73). The cost-benefit rationale for EU's geostrategic stake may be lost on the altar of "political correctness" (74).

The East-West conflict has been described as an instance of "value politics," thereby making the connection between ideology and the European crisis (75). However, the original idea that drove the EU, the link between economy (free trade), social progress for EU citizens, and peace (cf. Rome Treaty of 1957), did not develop into a broad project until the new millennium (cf. Charter of Fundamental Rights of the European Union of 2000). The point is that the link between the EU and human rights and, more broadly, democracy is an integral part of the "mature" project (76). Article 2 of the Treaty of Lisbon mentions pluralism, but it is unqualified (77).

On one interpretation, it is the definition of the central concepts "pluralism" and "democracy" that creates the disagreement. If democracy is limited to liberal democracy (cf. article 2 of the Treaty of Lisbon), illiberal democracy - which both Hungary and Poland view as the superior solution to the dysfunctional cum failed western "liberal nondemocracy" - is precluded beforehand (78). Defenders of liberal democracy criticize the way that illiberal democracy equates effectiveness with negations of checks-andbalances. Furthermore, Orbán's "workfare state" is perceived as an abandonment of the 
welfare state and the European Social Model because redistribution is solely mediated by work (79). If the narrow stakeholder theory's non-recognition of economic democracy is accommodated, the rule of law cluster (cf. fundamentals) is further challenged.

The rule of law budget conditionality, which the EU majority of countries favor as a correction and censure measure, is tailored to combat the analogy to benefit tourism at the inter-state level on behalf of deviant states and their selective attraction to EU's economic dimension of the European perspective. Apart from the controversy of letting recognition dictate redistribution, the representatives of the EU majority culture face predicaments: that identity politics becomes a mask - for them; and that a decision to give in to the prevailing EU ideology becomes a game strategy to win time... to show that Fukuyama is correct that recognition (cf. idealism) is the highest stake and that a national conservative agenda is exactly that: national conservative. Illiberal democratic capitalism opposes the EU's "hegemony of opinion" for the same reason (80).

\section{A Footnote Conclusion}

Accession talks are overshadowed by the crisis. Hungary's Enlargement Commissioner Olivér Várhelyi proposed a "decoupling" strategy that would give Albania the advantage over North Macedonia in spite of North Macedonia's superior performance concerning EU standards (81). Nevertheless, Albania may have reason to rethink the EU terms to avoid a parallel society in international relations, with a split between Islam and Christianity. The Big Philosophical Question concerns the fact that "the major legal systems of the world" coincide with the values of those nations that count as the (culmination of the evolution of) "civilized nations" (82), the opposite of a "pluralist conception" (83). Scrutiny of legal imperialism and pluralism with a view to passing consistent judgment on cases of illiberalism is warranted. The EU has to reconsider double standards when it comes to protection of fundamental human rights (84). A return to EU's non-mature model is an option. However, what the powerful EU states cannot do is to redraw the borders to get the European perspective they want.

\section{References}

(*) Acknowledgements: The authors warmly thank Stefano Busillo and Emanuele Vannata from the University of Salerno's EUWEB Legal Observatory for his excellent research and editorial assistance. The usual disclaimer applies.

(1) In the regional context of the Balkan States, the European perspective defined in terms of "respect for human dignity, freedom, democracy, equality, the rule of law and respect for human rights, including the rights of persons belonging to minorities" is mixed with anti-corruption and solidarity and, furthermore, a "special responsibility" to assist for the EU. See European Commission, Statement by President von der Leyen at the joint press conference with President Michel and Andrej Plenković, Prime Minister of Croatia, following the EU-Western Balkans Zagreb Summit, May 6, 2020, available at www.ec.europa.eu/commission/presscorner/detail/en/statement_20_825 (hereinafter 2020 Statement by President von der Leyen). For an account of stakeholder frameworks as interpretative tools, see A. MATWIJKIW, B. MATWIJKIW, A Look Behind the Legal Scene: Philosophical Stakeholder Responses to Fundamental Human Rights, in T. RUSSO, A. ORIOLO, G. DALIA (eds.), Solidarity and Rule of Law. The New Dimension of EU Security, Springer, 2022 (forthcoming) (hereinafter A Look Behind the Legal Scene).

(2) F. FUKUYAMA, Identity: The Demand for Dignity and the Politics of Resentment, New York, Farrar, Straus and Giroux, 2018. 
(3) M.C. BASSIOUNI, Introduction to International Criminal Law, $2^{\text {nd }}$ ed., Leiden, Martinus Nijhoff Publishers, 2013, p. 1003.

(4) F. FUKUYAMA, Identity: The Demand for Dignity and the Politics of Resentment, cit., p. 91.

(5) European Council in Action, Outcome of the Zagreb EU-Western Balkans video summit of 6 May 2020, 20 May 2021, pp. 3-4 (briefing) (hereinafter 2020 European Council in Action Briefing),

available www.europarl.europa.eu/RegData/etudes/BRIE/2020/642836/EPRS_BRI(2020)642836_EN.pdf.

(6) European Commission, European Semester Thematic Factsheet, Fight Against Corruption, 22 November 2017, available at www.ec.europa.eu/info/sites/default/files/file_import/europeansemester_thematic-factsheet_fight-against-corruption_en_0.pdf. Note that political tyranny is the only conflict-causality that (neo-)liberals accept.

(7) Fukuyama's position in The End of History and the Last Man, New York, Free Press, 1992 - where the globalization of western liberal democracy and free market capitalism was viewed as the culmination of the historical evolution - shifted in Trust: Social Virtues and Creation of Prosperity, New York, The Free Press, 1995. Fukuyama conceded there is no sharp separation of culture and economics. Concerning recognition and redistribution, Fukuyama's Identity: The Demand for Recognition and the Politics of Resentment, cit., ascribes priority to recognition. While the universal recognition that liberal democracy implies is reshaped by narrow alternatives based on nation, religion, ethnicity, etc., recognition cannot be transcended. Populist nationalism (claimed to be rooted in economic motivation) stems from the demand for recognition (cf. idealism) and therefore cannot be satisfied by redistribution (cf. materialism).

(8) For admission, a country's state performance and/or capacity must conform to these conditions:

- stability of institutions guaranteeing democracy, the rule of law, human rights and respect for and protection of minorities;

- functioning market economy and the ability to cope with competitive pressure and market forces within the EU;

- ability to take on the obligations of membership, including the capacity to effectively implement the rules, standards and policies that make up the body of EU law (the acquis), and adherence to the aims of political, economic and monetary union.

(9) Tension between the liberal and the "social market economy" is inescapable. See supra note 8 and infra note 66 .

(10) J.S. NYE, Transformational Leadership and U.S. Grand Strategy, in Foreign Affairs, Vol. 85, No. 4, 2006, p. 139.

(11) European Parliament, A New Approach to EU Enlargement (Briefing), 2 March 2020, pp. 2-3, available

www.europarl.europa.eu/RegData/etudes/BRIE/2020/649332/EPRS_BRI(2020)649332_EN.pdf.

(12) Commission to the European Parliament, the Council, the European Economic and Social Committee and the Committee of the Regions, 2020 Communication on EU Enlargement Policy, 6 October 2020, $\operatorname{COM}(2020) \quad 660$ final, available at www.ec.europa.eu/neighbourhoodenlargement/sites/default/files/20201006-communication-on-eu-enlargement-policy_en.pdf (hereinafter 2020 Communication on EU Enlargement Policy).

(13) Ibid., pp. 1-2, 6, 14-15, 17, 19, 27; Commission to the European Parliament, the Council, the European Economic and Social Committee and the Committee of the Regions, Enhancing the Accession Process $-A$ Credible EU Perspective for the Western Balkans, 5 February 2020, COM(2020) 57 final, pp. 1-7, available at www.eur-lex.europa.eu/legal-content/EN/TXT/PDF/?uri=CELEX:52020DC0057\&from=EN (hereinafter Enhancing the Accession Process). For the six policy clusters (the rule of law, the internal market, competitiveness and inclusive growth, green agenda and sustainable connectivity, resources, agriculture, and cohesion, and external relations), see id., p. 7.

(14) Enhancing the Accession Process, cit., pp. 1, 3-4.

(15) Ibid., p. 3.

(16) Ibid., pp. 1-3.

(17) "The EU is a strategic goal for us, but I will not condone anyone and speak out against China and Russia", Serbia's President Aleksandar Vučić stated. See A. SZUCS, T. OZTURK, Western Balkans Is 'Priority': EU Top Official, in Anadolu Agency, 6 May 2020, available at www.aa.com.tr/en/europe/western-balkans-is-priority-eu-top-official/1831836.

(18) 2020 Statement by President von der Leyen, cit.

(19) The fundamentals, referred to as "the rule of law cluster", contain eight sub-categories, including "judiciary and fundamental rights". See Enhancing the Accession Process, cit., p. 7. 
(20) 2020 Communication on EU Enlargement Policy, cit., p. 19.

(21) The EU policy resembles the UN 2004 strategy in response to threats to collective security: "to work across issues in a concerted fashion". See A. MATWIJKIW, B. MATWIJKIW, A Look Behind the Legal Scene, cit.

(22) 2020 Communication on EU Enlargement Policy, cit., p. 2.

(23) A. MATWIJKIW, B. MATWIJKIW, A Look Behind the Legal Scene, cit.

(24) M. MICHELOT, The article 7 Proceedings against Poland and Hungary: What Concrete Effects?, in Thinking Europe, 6 May 2019, available at www.institutdelors.eu/en/publications/_trashed/ (hereinafter The article 7 Proceedings against Poland and Hungary). Poland, which is currently the subject of article 7 proceedings for its assault on the nation's courts, is said to not "not want to set a precedent" by voting in favor of suspending the voting rights in the EU Council in the case of Hungary. See R. IDDIOLS, A. CASSIDY, Hungary 'has no place in the EU anymore, 'Dutch leader says, in CNN, 25 June 2021, available at www.edition.cnn.com/2021/06/24/europe/hungary-eu-lgbt-mark-rutte-intl/index.html.

(25) M. MICHELOT, The article 7 Proceedings against Poland and Hungary, cit.

(26) 2020 European Council in Action Briefing, cit., p. 1 [Authors' emphasis].

(27) Ibid., pp. 1-4; European Commission, Commission Proposes Renewed Consensus on Enlargement, 8 November, 2006, IP/06/1523,

www.ec.europa.eu/commission/presscorner/detail/en/IP_06_1523.

(28) European Commission, Commission Welcomes the Green Light to Opening of Accession Talks with Albania and North Macedonia, 25 March 2020, IP/20/519, available at www.ec.europa.eu/commission/presscorner/detail/en/IP_20_519.

(29) Ibid.

(30) European Commission, Commission Drafts Negotiation Frameworks for Albania and North Macedonia, 11 July 2021, IP/20/1021, available www.ec.europa.eu/commission/presscorner/detail/en/IP_20_1021.

(31) Ibid.

(32) R. MESSICK, President Biden: Fighting Corruption Core U.S. National Security Interest, in The Global Anticorruption Blog, 9 June 2021, available at www.globalanticorruptionblog.com/2021/06/09/president-biden-fighting-corruption-core-u-s-nationalsecurity-interest/.

(33) Enhancing the Accession Process, cit., p. 1.

(34) J. BORRELL, EU Needs to Change the Dynamic on Western Balkans, in Dit-Net, 21 May 2021, available at www.dtt-net.com/en/news/3271/39/Opinion-EU-needs-to-change-the-dynamic-on-WesternBalkans/.

(35) A. SANGIOVANNI, Solidarity in the European Union, in Oxford Journal of Legal Studies, Vol. 33, No. 2, 2013, pp. 213, 217. DOI: org/10.1093/ojls/gqs033.

(36) Ibid., p. 238.

(37) Ibid., pp. 234, 239.

(38) Ibid., p. 229.

(39) Ibid., pp. 227, 232.

(40) A. SANGIOVANNI, The Irrelevance of Coercion, Imposition, and Framing to Distributive Justice, in Philosophy \& Public Affairs, Vol. 40, No. 2, 2012, p. 79.

(41) A. SANGIOVANNI, Solidarity in the European Union, cit., p. 215. Note that "distributive" and "redistributive" justice are synonymous calls for a fair allocation of socioeconomic goods.

(42) R.E. FREEMAN ET AL, Stakeholder Theory: The State of the Art 230, Cambridge, Cambridge University Press, 2010.

(43) M. FRIEDMAN, Capitalism and Freedom, 40 ${ }^{\text {th }}$ ed., Chicago, Chicago University Press, 2002, pp. 7, $10,22$.

(44) Ibid., p. 8.

(45) A. MATWIJKIW, The Dangers of the Obvious but Often Disregarded Details in the International Criminal Law Demarcation Debate: Norm-Integration and the Triple-Thesis 'Argument', in International Criminal Law Review, Vol. 10, No. 2, 2020, p. 59.

(46) A. MATWIJKIW, B. MATWIJKIW, A Look Behind the Legal Scene, cit; UN General Assembly's Resolution 2200A (XXI), International Covenant on Economic, Social and Cultural Rights, 16 December 1996, art. 2; Council of Europe's Treaty n. 163, European Social Charter (Revised), 3 May 1996, arts. 13, 23 , and 31 . 
(47) Friedman relativizes harm, for "what one man regards as good, another man may regard as harm". Furthermore, interference with voluntary cooperation establishes the market paradigm of harm, with the exception of fraud and negligence. See M. FRIEDMAN, Capitalism and Freedom, cit., pp. 3, 7, 15, 105107, 113, 158, 162, 167, 195.

(48) R.E. FREEMAN, Strategic Management: A Stakeholder Approach, Cambridge, Cambridge University Press, 2010, p. 102.

(49) E.g., the Fair Opportunity Principle for Human Stakeholders prescribes "Stakeholders should not be discriminated against on the basis of characteristics which they cannot control through their own subjectivist and/or relativist choices (meaning that they depend on non-preferential factors to be able to acquire or un-acquire the relevant characteristics). They have a right to inclusion on the basis of humanity". The Ethics Pillar is the anti-dote to the "claims of nationalistic cultural rights" Bassiouni connects with western reluctance to show solidarity with "the hardship suffered by refugees fleeing wars, repressive regimes, economic exploitation, and poverty". See A. MATWIJKIW, B. MATWIJKIW, Bahrain Anno 2017: Peace or Regime Change? The Ongoing Human Rights Dilemma and the Ethics Pillar as a Measurement, in Global Community Yearbook of International Law and Jurisprudence 2017, 2018, pp. 131, 133 n9, 135 n18; M.C. BASSIOUNI, The Future of Human Rights in the Age of Globalization, in Denver Journal of International Law and Policy, Vol. 40, No. 1, 2012, pp. 21, 38. For the migrant as an "unreasonable burden" under Directive 2004/38/EC, para. 10, see A. SANGIOVANNI, Solidarity in the European Union, cit., p. 238.

(50) D. TILLES, "It is our duty to thank God for gifting the Kaczyńskis to Poland", says archbishop, in Notes from Poland, 19 June 2021, available at www.notesfrompoland.com/2021/06/19/it-is-our-duty-tothank-god-for-gifting-the-kaczynskis-to-poland-says-archbishop/. Note that Poland's President Andrzej Duda was a Presidential Candidate for PiS during the 2015 election, but resigned his party membership. He received the official support of the PiS for his 2020 re-election campaign).

(51) Under the TEU, there is no mechanism to expel a member.

(52) EU: Use article 7 Now to Protect European Values, in Human Rights Watch, 18 June 2021, available at www.hrw.org/news/2021/06/18/eu-use-article-7-now-protect-european-values.

(53) E.g., President Orbán was described as "a dictator". See S. WALKER, 'Hello, Dictator': Hungarian Prime Minister Faces Barbs at EU Summit, in The Guardian, 22 May 2015, available at www.theguardian.com/world/2015/may/22/hello-dictator-hungarian-prime-minister-faces-barbs-at-eusummit.

(54) Poland and Hungary file complaint over EU budget mechanism, in Deutsche Welle, 11 March 2021, available at www.dw.com/en/poland-and-hungary-file-complaint-over-eu-budget-mechanism/a56835979.

(55) E. ZALAN, Poland and Hungary Sanctions Procedure back after Pandemic, in Euobserver, 22 June 2021, available at www.euobserver.com/democracy/152211.

(56) M. MICHELOT, The article 7 Proceedings against Poland and Hungary, cit.

(57) This fight took place in 2005-2006. See Europa i krise - Identitetskrisen, in DK4, 5 March 2020, available at www.youtube.com/watch?v=WPqyx6JAMQc. For the "Christian roots" of the European perspective, see G. GALASSO, Into the Future of a Common Past, in G. AMATO ET AL (eds.), The History of the European Union: Constructing Utopia, Bloomsbury, 2019.

(58) A. MATWIJKIW, B. MATWIJKIW, Denmark's Blanket Burqa Ban: A National(ist) Perspective, in A. MATWIJKIW, A. ORIOLO (eds.), Law, Cultural Studies and the "Burqa Ban" Trend: An Interdisciplinary Handbook, Cambridge, Intersentia, 2021, pp. 349-389, 367 (hereinafter Denmark's Blanket Burqa Ban).

(59) Ibid., p. 383.

(60) M. FRIEDMAN, Capitalism and Freedom, cit., p. 21.

(61) A. MATWIJKIW, B. MATWIJKIW, Denmark's Blanket Burqa Ban, cit., p. 359.

(62) M. CLANTE BEDIXEN, The Massive Danish Discrimination, in Refugees.DK, 12 February 2019, available at www.refugees.dk/en/focus/2019/february/the-massive-danish-discrimination/; M. DAHL, N. KROG, Experimental Evidence of Discrimination in the Labour Market: Intersections between Ethnicity, Gender, and Socio-Economic Status, in European Sociological Review, Vol. 34, No. 4, 2018, p. 402. DOI: 10.1093/esr/jcy020; N. JENSEN-PETERSEN, Unemployed Immigrants Challenge Danish Tolerance, in The Murmur, 22 June 2021, available at www.murmur.dk/unemployed-immigrants-challenge-danishtolerance/; T. JOHN. S. GARGIULO, Denmark Is a Liberal Paradise for Many People, but the Reality Is Very Different for Immigrants, in CNN, 20 July 2020. 
(63) European Court of Human Rights (Grand Chamber), Judgment of 1 July 2014, Application No. 43835/11, S.A.S. v. France, paras. 53-54.

(64) T. GAMMELTOFT-HANSEN, Refugee Policy as 'Negative Nation Branding:' The Case of Denmark and the Nordics, in Danish Foreign Policy Yearbook, 2017, pp. 99, 102.

(65) Ibid., p. 109.

(66) M. FRIEDMAN, The Social Responsibility of Business is to Increase Its Profits, in The New York Times Magazine, 13 September 1970.

(67) M. DE LA BAUME, European Parliament Declares Abortion Access a Human Right, in Politico, 24 June 2021, available at www.politico.eu/article/meps-adopt-divisive-text-on-abortion/.

(68) Ibid.

(69) M. DE LA BAUME, MEPs Overwhelmingly Condemn Hungary's Anti-LGBTQ+ Law, in Politico, 8 July 2021, available at www.politico.eu/article/meps-overwhelmingly-condemn-hungarys-anti-lgbtq-law/. (70) G. BACZYNSKA, R. EMMOTT, Hungary Rejects EU Demand to Ditch 'Shameful' Anti-LGBT Law, in Reuters, 7 July 2021, available at www.reuters.com/world/europe/a-disgrace-hungary-must-ditch-antilgbt-law-eu-executive-says-2021-07-07/.

(71) Ibid.

(72) For a comparative analysis of Feuerbach and Marx/Engels, see B. MATWIJKIW, Philosophical Analysis as a Pathway to Progress: From the Burqa to the Emperor's New Clothes, A. MATWIJKIW, A. ORIOLO (eds.), Law, Cultural Studies and the "Burqa Ban" Trend: An Interdisciplinary Handbook, Cambridge, Intersentia, 2021, pp. 55-80.

(73) S. RANDERIA, Orbán's Lawfare against Liberal Democracy in Hungary, in Global Challenges, No. 2, 2017, available at www.globalchallenges.ch/issue/2/orbans-lawfare-liberal-democracy-hungary/.

(74) Orbán: Liberal Democracy Has Become 'Liberal Non-Democracy', in Daily News Hungary, 6 May 2021, available at www.dailynewshungary.com/orban-liberal-democracy-has-become-liberal-nondemocracy/ (hereinafter Daily News Hungary).

(75) Europa i krise - Identitetskrisen, cit.

(76) Ibid.

(77) "The Union is founded on the values of respect for human dignity, freedom, democracy, equality, the rule of law and respect for human rights, including the rights of persons belonging to minorities. These values are common to the Member States in a society in which pluralism, non-discrimination, tolerance, justice, solidarity and equality between women and men prevail". See Treaty of Lisbon (2007), art. 2, available at www.lisbon-treaty.org/wcm/the-lisbon-treaty/treaty-on-european-union-and-comments/title1-common-provisions/2-article-2.html.

(78) Daily News Hungary, cit.

(79) D. SZIKRA, Welfare for the Wealthy: The Social Policy of the Orbán-regime, 2010-2017, in Friedrich Ebert Stiftung, March 2018, www.library.fes.de/pdf-files/bueros/budapest/14209.pdf.

(80) Daily News Hungary, cit.

(81) J. BARIGAZZI, EU Commissioner Floats Shift on Albania Membership Talks, in Politico, 7 May 2021, available at www.politico.eu/article/eu-commission-albania-membership/.

(82) Ibid.

(83) F.O. RAIMONDO, General Principles of Law in the Decisions of International Criminal Courts, Leiden-Boston, Brill, 2008, pp. 182-183.

(84) E. INOTAI ET AL, Democracy Digest: Hungary and Poland Refuse to Join EU Justice League, in Balkaninsight.com, Reporting Democracy, 4 June 2021, available at www.balkaninsight.com/2021/06/04/democracy-digest-hungary-and-poland-refuse-to-join-eu-justiceleague/.

\section{ANTI-CORRUPTION AND ANTI-MONEY LAUNDERING: CRIMINAL NETWORKS AND PREVENTION MODELS COMPARED}

